\title{
The Land Use and Soil Protection: Planning and Legal Regulations in Serbia
}

\author{
Ljubiša Bezbradica*a, Marijana Pantića $^{*}$, Aleksandra Gajića \\ anstitute of Architecture and Urban \& Spatial Planning of Serbia, Bulevar Kralja Aleksandra 73/II, 11000 \\ Belgrade, Serbia \\ *Corresponding author: ljubisa@iaus.ac.rs
}

\begin{abstract}
Land, as one of the basic environmental factors, is under large impact by intensive agricultural production, urbanisation, mining activities, erosion caused by anthropogenic factors, etc., which can easily result in its degradation. The unplanned land use increases the risks of degradation and reduction of the land resource. Chemical pollution, unfavourable physical and mechanical characteristics, disruption and accumulation processes, infrastructural occupancy of land represent only few forms of the land degradation. The largest portion of the land in the Republic of Serbia is covered by forests, and only then agricultural, water and construction land. The land use, management and protection is regulated by legislation and planning documents, which are the object of this paper. In the first part of the document analysis, the focus is on the review of the relevant laws adopted in Serbia, such as the Law on Forests, the Law on Spatial Planning and Construction, the Law on Environmental Protection, the Law on Land Protection, and the Law on Agricultural Land, bearing in mind the fact that the legislation forms a basis for further implementation of the planning management and supervision of the land use of all types and purposes. The other part of the review deals with the planning acts as pioneering documents in the integral overview of space, and/or all the activities in it. To that purpose, several spatial plans for different types of areas and different primary functions of land use have been chosen. In its conclusion, this paper explains the symbiosis of legislation and planning documents, and/or their implementation, as well as the significance of such symbiosis for the land function and its sustainable utilisation in the Republic of Serbia.
\end{abstract}

Keywords: land use, land protection, legislative, spatial planning, Serbia.

\section{INTRODUCTION}

Out of the total $88,361 \mathrm{~km}^{2}$ of the territory area of the Republic of Serbia, $53.76 \%$ or $47,502.173 \mathrm{~km}^{2}$ is agricultural land. The major part of it is located in the territory of the Autonomous Province of Vojvodina $\left(19.69 \%\right.$, or $17,397.92 \mathrm{~km}^{2}$ ) and its Pannonian Plain terrain intersected by rivers and canals (Josimović et al.).

In the face of the land resources overload reduction due to the migration of population from rural parts of Serbia, especially in the mountain region (Stojkov, Pantić, 2007), in the past few decades the mankind has been faced with the excessive use of natural resources, causing substantial changes in the quality of the environment. Urban development and the increasing population, causing the ever-growing demand for food, have generated intense 
agricultural production and the growing risk of land degradation processes. Due to these great pressures on natural resources, as well as to deforestation, unplanned use of land etc., the land fund has degraded and reduced. Because of the above-listed negative impacts on land resources, land losses resulting from erosion, both natural and anthropogenic, contribute to the negative trend of decreasing the area of agricultural, forest and water lands. Apart from direct negative impacts on land, such as chemical pollution, unfavourable physical and mechanical characteristics, destruction processes, infrastructural occupancy of land, drainage and pollution of water supply accumulations and electric power production, land as a key resource is also affected by mining activities in large mines in the Republic of Serbia, which intensifies the repurposing of forest and agricultural land into mining land.

The law is a normative act of the state enacted by its legislative authority in line with the prescribed procedure. In the course of producing legal regulations in the Republic of Serbia, they legislature is being harmonised with that of the European Union as a prerequisite for the accession to EU. European regulations are characterized by integrity and/or striving for the implementation of measures and obligations for the sake of realizing previously defined goals and visions. The implementation of EU laws affects all segments of the functioning activity with the aim of achieving sustainable management of land resources. The Government of the Republic of Serbia, as the executive authority, enacts laws and other general acts, i.e. adopts regulations and other general acts aimed at the implementation of the law. When a law comes into force, all the subjects it refers to are obliged to act in line with it. Management, protection and preservation of land resources in the Republic of Serbia are regulated by the following laws: the Law on Forests, the Law on Agricultural Land, the Law on Spatial Planning and Construction, the Law on Land Protection, the Law on Environmental Protection etc. Having in mind that the major part of the territory of the Republic of Serbia consists of forests and forest land and/or agricultural land, legal regulations in the field of forests and agriculture, environmental and nature protection constitute the primary and most important legal field in exploitation, arrangement and preservation of land resources.

Planning regulations represent the basis for using and managing natural resources, i.e. the acts which implement guidelines for space preservation and protection, and measures of sustainable use of land resources. The realization of planning documents is a test of willingness of institutions and/or legal and natural entities towards harmonizing all segments of the society, the present state and the vision of future (Bezbradica, 2013). 
Review paper: doi:10.5937/ZemBilj1902051B

This paper presents basic provisions of the above-listed legal acts from the aspect of using land categories with the greatest biodiversity value - agricultural and forest land respectively.

\section{METHODOLOGY}

This paper represent a review of existing legal documents that are related explicitly or implicitly to the land use and soil protection in Serbia. The review of the legislative framework included not only laws, but also spatial plans because these documents are equally obligatory as ordinary legislative acts. In addition, land use is in the focus of spatial planning, for which spatial plans play the leading role in regulation of not only soil protection but also land and soil use.

This paper goes into details regarding the Law on Agricultural Land (2006), Law on Environmental Protection (2009), Law on Spatial Planning and Construction (2009), Law on Forests (2010) and the Law on Land Protection (2015).Even though interpretation of the spatial planning practice in land and soil use and protection is mainly interpreted through the Law on Spatial Planning and Construction, the output of this paper is additionally based on series of documents involved in spatial planning practice and specific spatial planning acts such as the Spatial Plan for the Kostolac's Coal Basin Special Purpose Area (2013) or Spatial Plan for the "Prvonek" Storage Basin Special Purpose Area (2017).

The main goal of the paper is to give a comprehensive preview of the contemporary foundation for treatment of land and soil in Serbia.

\section{REVIEW OF LEGISLATIVE ON LAND USE AND PROTECTION IN SERBIA}

The primary role of the legal regulations regarding land resources in the Republic of Serbia is arrangement, protection and planned use, land-registry management and supervision of the law implementation. Other legal acts and bylaws are indirectly connected with the implementation of the laws in the fields of forestry, agriculture, environmental protection, water management, spatial and urban planning. Integrity, interconnection and interdependence are the obligation of the legislative authority in charge of enacting laws, as well as of the executive authority in charge of implementing legal regulations. In case of the Republic of Serbia, the following ministries act as law-enforcing agencies: the Ministry of Agriculture, Forestry and Water Management; the Ministry of Environmental Protection; and the Ministry of Construction, Transport and Infrastructure. 


\section{Law on Forests}

The Law on Forests recognizes forests as habitats of various plant and animal species with a multiple functional role: protecting land from erosion, positively affecting the quality of air, water and soil, being used in the wood industry, and being utilised for recreation and tourism purposes. Therefore, forests are recognized as one of the most important resources of the environment.

The catchment area without any protective vegetation cover and with unfavourable terrain and climate characteristics constitutes the basis for the occurrence of intense erosion processes in whose prevention forests play a key role manifested in several stages:

- protection from destruction of the land structure due to intense precipitation;

- soil binding with the aid of vegetation root systems;

- prevention of surface drainage, absorption of precipitation and gradual infiltration;

- improvement of mechanical features of soil in forming underground drainage and infiltration.

Forest coverage of the Republic of Serbia is $29.1 \%$ ( 0.7 ha per capita), which is similar to the world average of $30 \%$, but substantially lower than the European average of $46 \%$ (Public Utility Enterprise "Srbijašume”, 2019). Out of 78 forest species in the territory of the Republic of Serbia, the most common is beech $-20.6 \%$, followed by Turkey oak $-13.0 \%$, sessile oak $-5.9 \%$ and Hungarian oak $-5.8 \%$ (the Ministry of Agriculture, Forestry and Water Management of the Republic of Serbia, the Forest Directorate, 2009).

The Law on Forests regulates forest preservation, protection, planning, silviculture, utilization and management of forests and forest lands, the supervision of the implementation of this Law, as well as other issues significant for forests and forest lands. Forest, in terms of the law, includes: land area of more than $500 \mathrm{~m}^{2}$ covered with forest trees and land covered with minimum $30 \%$ of tree crowns, nurseries, protection belts, parks, belts under transmission line corridors (the Republic of Serbia, the Law on Forests).

The Law on Forests (2009) defines forest land as "the land on which a forest is cultivated, the land on which, because of its natural characteristics, it is more rational to grow a forest, as well as the land covered with the features intended for forest and game management and for multiple-use forest functions, and which cannot be used for other purposes, except in cases and under the conditions laid down by this Law" (the Republic of Serbia, the Law on Forests). 
Review paper: doi:10.5937/ZemBilj1902051B

The public interest of the Law on Forests is preservation, protection, use and raising new forest plantations. Defining forest areas, national parks and regions on the basis of natural, geographical or planned characteristics and their inventory constitutes the basis of planned management and implementation of the provisions of the law. Planning documents for forest management in the territory of the Republic of Serbia are:

- forestry development program

- regional forest development plan

- basics of forest management

- forest management program

Article 9 of the Law on Forests stipulates the measures of forest preservation through a series of prohibitions such as:

- forest devastation and clearing;

- clear cutting which is not authorized as the regular form of forest regeneration;

- any cutting which is not in accordance with the forest management plans;

- cutting of protected and strictly protected tree species;

- tree girdling; grazing or pasturing cattle, and acorn feeding in forest;

- harvesting of other forest products (mushrooms, fruits, medicinal plants, snails etc.);

- cutting of seed stands and seed trees, which is not prescribed by forest management plans;

- quarrying of stone, gravel, sand, humus, earth and peat, except for the construction of infrastructure for forest management;

- unauthorized occupation of forests, destruction or damage to forest plantations, marks, and border signs, and the construction of improvements which are not in the function of forest management;

- discharge of garbage and harmful and dangerous substances and waste, as well as forest contamination in any manner.

Vulnerability of forests and forest land has a constantly upward trend, particularly nowadays, due to the increasing population, i.e. the increasing needs for agricultural and construction land. Repurposing forest land into construction land (development of road infrastructure, expansion of settlements, tourism and recreation) and mining land, apart from the illegal cutting, intensifies the processes of the reduction in the forest and land fund and increases the risks of erosion processes. Article 10 of the Law on Forests allows for the repurposing of forests and forest lands only in the following cases: 
- when it is laid down by the regional forest development plan;

- if it is required by the public interest laid down by special law or the Government act;

- for the construction of the improvements for the protection of citizens and material goods from natural disasters, and for national defence;

- in the procedure of redistribution and consolidation of agricultural land and forests;

- for the construction of auxiliary buildings or dwelling houses for forest owners on the area of less than $1,000 \mathrm{~m}^{2}$;

- for the construction of the facilities for the use of other renewable energy sources of small capacity (small power plants and other similar improvements, in the terms of regulations in the field of energetics) and exploitation of mineral resources, if forest and forest land area for these purposes is below 15 ha.

The change in forest land-use form under Paragraph 1, Items 4) to 6) of this Article, shall be done with the approval from the Ministry.

The request for approval under Paragraph 2 of this Article, for the purpose of preventing fraudulent activities and misuse of forests as a valuable resource, the Law defines the obligation of submitting documentation that includes proof of ownership, i.e. of the right to use forests or forest land subject to approval; forestry inspection records on the existing state regarding the harvesting methods of forests and forest lands subject to approval; proof that the administrative tax is paid; and, in certain cases, project of reinstatement.

Prior to the establishment of the planned land use, the forest and forest land for which land-use change was performed shall be managed by the forest owner, i.e. forest user. At the request of the owner, the land-use form can be changed for the forest land of up to $5,000 \mathrm{~m}^{2}$ owned by the forest owner, which is registered as a forest or forest land in the official records and used for agricultural production.

Penal provisions of the Law on Forests comprise sanctioning measures for management and acting contrary to the provisions of the Law, i.e. fines in the amount from 10,000 to 3,000,000 dinars for physical and legal persons, as well as the confiscation of the products obtained through actions which are not in compliance with the provisions of the Law on Forests.

\section{Law on Agricultural Land}

Agricultural land is one of the most important natural resources used for the production of food and/or raw materials for food industry as a direct product of agricultural production. 
Agricultural land accounts for approximately $53 \%$ of the overall territory of the Republic of Serbia, or 0.67 ha per capita. In order to preserve the available agricultural land and create prerequisites for preventing degradation and pollution, it is necessary to achieve sustainable management and utilization of land resources intended for agricultural production.

The Law on Agricultural Land (2006) constitutes the basis for sustainable management of agricultural land; namely, this Law regulates planning, protection and utilization. For the purpose of sustainable utilization, protection and arrangement of agricultural land, it is necessary to produce and implement planning documents, i.e. agricultural basics harmonized with spatial and urban plans. The protection of agricultural land is also defined in the provisions of Articles 16, which stipulate that "it is forbidden to discharge and dispose of dangerous and harmful substances on agricultural land and in irrigation and drainage canals; it is forbidden to use biologically non-degradable foil on arable agricultural land." In order to protect agricultural land from harmful effects of erosion and floods in the erosion area, Article 18 of the Law on Agricultural Land stipulates anti-erosion measures. The abovementioned anti-erosion measures include: temporary or permanent prohibition of repurposing meadows and pastures and other areas with the aim of their conversion into arable land covered with annual crops;

- introduction of crop rotation;

- cultivation of perennial plantations;

- construction of specific building structures;

- method of agricultural land cultivation;

- raising and cultivation of field-protection belts or planting perennial woody plants;

- prohibition of cattle pasturing for a limitedperiod of time or restricting the number of heads of cattle that may be let to specific areas;

- prohibition of wood cutting and wood plantations beyond endangered plots.

The prohibition provisions in the function of land protection include: prohibition of destroying and damaging crops, seedlings, trees and agricultural machinery at estates; prohibition of burning organic remains after crop harvest and prohibition of cattle pasturing on arable agricultural land, except on someone's own land. While the arrangement of agricultural land and obligations of users are considered as a basic prerequisite for preserving and protecting land resources, which includes procedures such as irrigation and drainage systems; re-cultivation of land degraded after mineral and other resources exploitation; and 
Review paper: doi:10.5937/ZemBilj1902051B

transformation of non-arable into arable land and improvement of the quality of arable agricultural land.

The obligations of legal and natural entities stipulate that the user regularly cultivates land, applies legally prescribed measures and acts with the care of a prudent owner in line with the rules of the good agricultural practice code.

Negative effects of agricultural land management are reflected in the permanently decreasing area of land resources in agriculture. In order to reduce that problem to minimum, Article 23 of the Law stipulates the following that the arable agricultural land can be used for non-agricultural purposes in the following cases:

- for creating artificial meadows and pastures on agricultural farmland of fourth and fifth cadastral classes, as well as for creating forests regardless of the class of land;

- for exploitation of mineral resources (clay, gravel, sand, peat, stone etc.) and/or performance of works of disposal of tailings, ash, slag and other dangerous and harmful substances on arable agricultural land for a limited period of time with the previously obtained approval from the Ministry and enclosed proof of payment of the fee for repurposing of agricultural land determined by the local self-government's resolution;

- in any other cases when public interest has been established based on the law, with the payment of the fee for such repurposing.

In some cases, such as the case described in Paragraph 1 of this Article, it is allowed to use land for a limited period and for an indefinite period of time.

Sanctions for the failure to act in line with the law stipulate fines in the amount from 5,000 to $1,000,000$ dinars.

\section{Law on Land Protection}

The Law on Land Protection integrates the lands of all purposes, properties and methods of use, i.e. this Law regulates the protection and monitoring of land resources in the Republic of Serbia. This Law is aimed at sustainable utilization which unifies the principles of preservation, integrity and financing of land utilization. Such established basis should resolve the problem of degradation processes occurring on land due to the following:

- inadequate agricultural and forest production;

- uncontrolled repurposing of land;

- inadequate and unplanned management, utilization and urbanization; 
Review paper: doi:10.5937/ZemBilj1902051B

- mining activities and exploitation;

- chemical pollution;

- erosion; and

- physical and mechanical damage of land.

Planning prevention measures of land protection and preservation involves the production of planning and program documents and their integration and/or harmonization with other planning, spatial and urban planning documents. Measures and conditions of land protection aimed at sustainable utilization of land are integral part of planning and project documentation. Strategic environmental impact assessment of plans and programs (SEIA) is integral part of planning documentation and SEIA actually defines potential harmful impact on land resources, stipulating protection measures and conditions (the Law on Land Protection, 2015).

Prevention and/or protection measures and activities are defined in the provisions of the Law in Article 13, stating that land protection is performed on the basis of adopted international contracts, prescribed measures and activities, in particular:

- system monitoring of the state and quality of land with the aim of keeping morphological, physical, chemical and biological characteristics;

- monitoring the indicators of the state of land and risk of land degradation;

- monitoring, predicting and preventing activities that may or actually cause harmful changes in land;

- planning and integrating land protection measures in sector policies and plans;

- establishing rights, obligations and responsibilities of owners and/or users of land;

- monitoring the impact of surface and ground waters on land;

- control, restriction and prevention of taking pollutants and dangerous and harmful substances into or on land;

- application of procedures of land rehabilitation, remediation and recultivation;

- performing the inspection supervision, and

- other supervision of the work of land protection subjects.

In order to protect the land in the territory of the Republic, the following land protection documents are adopted:

- Land Protection Plan;

- Annual Land Protection Program, and

- Land Monitoring Program. 
Degradation or indirect loss of land constitutes the repurposing of agricultural, forest and water lands for mining activities, infrastructural facilities, tourist purposes etc. Negative effects are reflected in potential implications, i.e. degradation and pollution of the widerranging environment, including land. The change in land-use form is also defined in the Law on Land Protection, together with the obligation of obtaining the approval of the Ministry.

The definition of land protection and rehabilitation measures includes activities intended to prevent actions that lead to indirectly and directly negative impacts on land. Rehabilitation and/or improvement of degraded and polluted land are achieved through remediation and recultivation of polluted land or land that needs re-formation of the soil layer with the aim of cultivating plant communities.

Land protection measures include prohibition and/or restriction of performing activities aimed at the prevention of:

- unplanned and/or uncontrolled change in land-use form regarding agricultural land;

- conversion of forest land into agricultural land;

- discharge and disposal of dangerous and harmful substances and waste waters on the surface and into land;

- method of agricultural land cultivation that is not in compliance with the terrain configuration and relief;

- negative effects of soil structure;

- reduction in the biological activity of land;

- land compaction;

- exceeding the optimal number of heads of cattle in line with the natural characteristics of the location;

- erosion;

- reduction of the level of organic substances in the soil in comparison to the level of natural content;

- inadequate use of mineral and organic fertilizers;

- inadequate application of plant protection products and other preparations;

- inadequate utilization and arrangement of agricultural land;

- unplanned and uncontrolled wood cutting;

- planting trees that are not suitable for the habitat;

- uncontrolled and/or unplanned exploitation of mineral and organic resources;

- prohibited archaeological excavations and research; 
Review paper: doi:10.5937/ZemBilj1902051B

- unplanned and/or uncontrolled exploitation of gravel and sand from riverbeds, watercourses and their impact areas.

Penal provisions of the Law stipulate fines in the amount from 5,000 to $3,000,000$ dinars.

\section{Law on Environmental Protection}

The Law on Environmental Protection indirectly serves to preserve land resources of the Republic of Serbia. Protection and preservation are the key to preventing degradation processes of all environmental factors, with land being among the most important ones.

All users of the environment are responsible for the activities that may lead to the change in the state of environment, which means that they are obliged:

- to use natural resources rationally

- to invest inprotection measures during exploitation

- to protect the environment.

The definition of certain principles of protection achieves integration and harmonization of laws, plans, regulations, programs etc; rehabilitation and improvement of the quality of natural resources; removing consequences, repair of damage and the right to live in the healthy environment.

Sustainable utilization and protection are ensured within the Strategy of Spatial Development of the Republic of Serbia ("Strategy") and the National Strategy for Sustainable Use of Natural Goods and Resources (NS). In line with the Strategy and NS, the production of plans and programs for managing natural goods and resources is initiated. Prevention measures and protection conditions are defined in spatial and urban plans:

- by establishing special regimes of preservation and utilization;

- by determining the endangered parts of the environment and establishing rehabilitation measures etc.

The Strategic Environmental Impact Assessment (SEIA) and the Environmental Impact Assessment (EIA) are performed for the purpose of assessing the impact of strategies, plans, programs and basics, i.e. projects on the environment, and they constitute integral part of planning and project documentation.

The planning and management of environment protection are achieved and ensured by the National Program of Environmental Protection whose role is in integral protection. The Action Plan is an instrument that implements the National Program of Environmental 
Review paper: doi:10.5937/ZemBilj1902051B

Protection A recovery plan is enacted in the cases where there is a risk of a permanent disturbance of the quality of the environment.

According to the Law, Article 22 defines land protection measures, stating that "protection of land space (land) and its sustainable utilization shall be ensured by the measures of systematic monitoring of the quality of land, monitoring the indicators of risk assessment for land degradation, as well as implementing the remediation programs for removing consequences of contamination and degradation of the land space, either natural or man-made. When changing the holder of the right to use land, the land user whose right of use ceases and whose activity affected or may have affected or disturbed natural functions of land, is obliged to produce a report on the state of land.

"The government shall prescribe systematic monitoring of land quality, the indicators of land degradation risk assessment, and methodology for preparation of remediation programmes from Paragraph 1 of this Article.

"The Minister shall determine the content and methodology of producing reports on the state of land."

Apart from defining land protection measures, the provisions of the Law also contain:

- water protection measures,

- air protection measures,

- forest protection measures, and

- flora and fauna protection measures.

Monitoring, limit values and allowed values of land and soil are among the most important paragraphs in the provisions of the Law. Public participation is of great significance in the procedures of producing documents for protection and preservation of natural resources, as well as in the integrated system of monitoring, notification and other activities that comprehensively affect the control and implementation of the provisions of the Law on Environmental Protection.

Penal provisions of the Law on Environmental Protection stipulate fines in the amount from 5,000 to 3,000,000 dinars (the Republic of Serbia, the Law on Environmental Protection).

\section{Law on Spatial Planning and Construction}

The Law on Spatial Planning and Construction defines, among other things, the space arrangement and/or conditions and methods of space arrangement and utilization. The 
principles on which sustainable space utilization are based constitute an integral approach of planning and/or rational utilization of land and other natural resources (the Republic of Serbia, the Law on Spatial Planning and Construction).

This Law defines the obligations of producing and implementing planning documents which include spatial plans, urban plans, strategies and programs of implementation. The assessment of the current state and/or principles, protection measures, preservation and arrangement of the nature and natural systems of the environment constitutes integral part of the planning documentation.

The repurposing of agricultural and forest land into construction land is defined in planning documents, in line with the provisions of the Law on Spatial Planning and Construction. The method and procedure of changing the purpose of agricultural land defined in Article 88 (the Law on Spatial Planning and Construction, 2009).

When the use of agricultural and forest land is changed to construction land through a planning document, the agency responsible for producing the plan is obliged to deliver a document to the agency responsible for state land surveying affairs and land-registry, containing a list of land-registry plots whose use has been changed, or the description of the limits of the planning document with the list of land-registry plots and the adequate graphic representation, within 15 days from the day of enactment of the planning document.

The agency responsible for state land surveying affairs and land-registry implements the arising changes through a resolution, and enters a record of the obligation of payment of compensation for the change of use of agricultural land into the database of the real estate land-registry which issues the real estate folio, within 15 days from the receipt of the act from Paragraph 1 of this Article.

Prior to the establishment of the planned land use, the agricultural land the purpose of which has been changed through a planning document can be used for agricultural production.

The resolution from Paragraph 2 of this Article is submitted to the land owner, the Ministry responsible for agricultural affairs and the relevant tax authority within 15 days from the issuance of this resolution.

The owner of the land-registry plot for which the use is changed is obliged to pay compensation for the change of use of agricultural land before the issuance of a construction permit, in compliance with the law governing agricultural land or the law governing forest land. 
If the purpose and/or type of land from agricultural into construction land was changed on the basis of the law, the planning document, and the resolution of the relevant authority, or if a planned building was constructed in line with the law until 15th July 1992, i.e. until the day of enactment of the Law on Agricultural Land ("Official Gazette of the Republic of Serbia”, No. 49/92), no compensation shall be paid for the change of the purpose of the land, regardless of whether the land was recorded as a farm, a vineyard, an orchard, a meadow, a pasture, a reed marsh or infertile land.

No compensation shall be paid for changing the purpose of agricultural and forest land into construction land when structures of importance for the Republic of Serbia are built on it, as well as for the construction of public purpose facilities in line with the program of construction land arrangement, when the compensation shall be covered by the Republic of Serbia, the autonomous province and/or the local self-government, as well as public utility enterprises founded by the Republic of Serbia, the autonomous province and/or the local selfgovernment.

The change in land-use form from forest to construction land contained in the planning document is considered as public interest pursuant to Article 10 of the Law on Forests (“Official Gazette of the Republic of Serbia", No. 30/10, 93/12 and 89/15).

From the date of enactment of the planning document governing the change of purpose of agricultural and forest land into construction land, the owner of such land shall have all the ownership rights over the construction land in line with this Law.

Upon the proposal of the Ministry in charge of construction affairs, the Government shall determine the projects for building structures of importance for the Republic of Serbia.

\section{PLANNING DOCUMENTS IN THE FUNCTION OF LAND USE, LAND PROTECTION AND PRESERVATION}

Planning documentation constitutes an overall set and mutual interaction of interconnected partial factors of inhabitation, economic and social activities and needs. The most important characteristics in the planning process are: integrity, compliance, coordination and determination of obligations and responsibilities in the production and implementation of plans. Therefore, spatial planning comprises the set of indirect and direct measures related to land and its quality improvement (Pantić, 2016).

Space arrangement and utilization are based on the principles of sustainable development; encouragement of equal regional development; compliance of social 
development, economic and energy efficiency and the protection and revitalization of the environment and building heritage, natural, cultural and historical values; realization of development priorities and ensuring conditions for the rational use of non-renewable natural sources and renewable energy sources; prevention and protection from natural and technical and technological disasters; space planning and arrangement for the country defence requirements and construction of facilities of special significance for the country defence; participation of the public; cooperation between state authorities, autonomous territorial communities, local self-governments, business entities, institutions, non-governmental organizations, citizens and other participants in the spatial development; compliance with the European standards and norms in the field of space planning and arrangement with the aim of creating conditions for transboundary and international cooperation and inclusion of the Republic of Serbia in the European integration processes.

The planning regulations in the Republic of Serbia consist of: planning documents, documents for the implementation of spatial plans and urban and technical documents. Planning documents are spatial and urban plans. Spatial plans include: Spatial Plan of the Republic of Serbia; Regional Spatial Plan; Spatial Plan of Local Self-Government and Special Purpose Area Spatial Plan. Urban plans include: General Urban Plan; General Regulation Plan and Detailed Regulation Plan. Documents for the implementation of spatial plans are: Implementation Program of the Spatial Plan of the Republic of Serbia and Implementation Program of the Regional Spatial Plan. Urban and technical documents for the implementation of planning documents are: urban design; re-partitioning and partitioning design; and elaboration of geodetic works for correcting the borders of adjoining plots and connecting two adjoining plots with the same owner. SEIA and EIA are integral part of the planning and project documentation (the Law on Spatial Planning and Construction, 2009).

Planning documentation has the primary role in the protection and preservation of land resources. Apart from spatial and urban plans, SEIA and EIA represent the analysis of the impact of plans and projects on the environment. Spatial and urban plans will ensure: protection and arrangement; improvement of infrastructural and communal fit-out; improvement of the quality of life, guidelines for the institutional-organizational and management-control support, sustainable use and protection.

Planning spatial activities constitutes an integral overview of all factors and/or users of the environment. Planned trade, economic and social development is, as a priority, 
Review paper: doi:10.5937/ZemBilj1902051B

harmonized with the environmental preservation and protection, i.e. rational use of natural resources.

The Special Purpose Area Spatial Plan is enacted for the areas which need a special regime of space organization, arrangement, utilization and protection. An area with the possibility of exploiting mineral resources and/or an area with the possibility of using the hydro potential are only some of the areas where the preparation of the Special Purpose Area Spatial Plan is compulsory.

The following are only some of the land protection and preservation instruments: the current state (SWOT) analysis; goals, principles and operational goals of the special purpose area spatial development, concept of the special purpose area spatial development; concept and proposition of protection, arrangement and development of the nature and natural systems; special purpose function spatial development, distribution of activities and land utilization; measures of protection, arrangement and improvement of natural and cultural resources; environmental protection measures; implementation measures and instruments for a special purpose area spatial plan and priority planning solutions; implementation measures for the Special Purpose Area Spatial Plan.

Thanks to their conditions, measures, guidelines etc., the planning solutions of the Special Purpose Area Spatial Plan have positive effects on the land protection, preservation and quality. The Special Purpose Area Spatial Plans for the basins of accumulations and mines stipulate the following:

- definition of accumulation zones and/or measures and conditions of utilization in them

○ establishment of strict sanitary supervision with the prohibition of building structures and facilities not intended for water management;

○ disposal of all types of waste is forbidden;

○ wastewater treatment is forbidden;

- exploitation of stone, gravel or sand and any other mining works are forbidden;

○ use of pesticides, herbicides, insecticides and chemical fertilizers is forbidden;

- controlled utilization of space and constant sanitary supervision with the prohibition of building structures which endanger soil and water;

- utilization and arrangement of agricultural land involves:

$\circ$ in zone I, the land surrounding the accumulation shall not be used for agriculture; 
0 in zone II, the agricultural land surrounding the accumulation will be used with restrictions (of the utilization degree of chemical preparations in crop production; controlled use of watering places for livestock; prohibited storage of agricultural and technical substances in the open space and prohibited handling that would lead to their access to watercourses; prevented discharge of liquid organic fertilizers into soil and watercourses;

$\bigcirc$ in zone III of the accumulation the principles of rational utilization of agricultural land apply (Spatial Plan for the "Prvonek" Storage Basin Special Purpose Area, 2017).

- in achieving sustainable rural development, it is important to provide support of the budget funds from the relevant ministry for:

○ equipping and introducing standards and raising perennial plantations;

○ supporting environmental protection;

- forest utilization and arrangement involve:

○ production and enactment of management programs;

$\circ$ preservation of the composition and improvement of the structure of stands of trees and increasing the forest coverage;

- anti-erosion protection of forest-covered areas and on forest land will be achieved by: artificial recovery and creation of new forests, i.e. by applying various biological and biotechnical anti-erosion works (culture filling, forestation, covering cuts with grass, putting up wickerwork fences and small walls against denudation etc.);

○ forest fire protection;

- for mines:

○ re-cultivation of landfills of tailings and ash;

- re-cultivation of all external landfills of overburden, the largest part of internal landfills in mines and some post-mining facilities;

○ raising emission forests around endangered settlements, protection greenery belts around mines and along roads;

- reduced use of mineral fertilizers and pesticides in plant production, support to the development of livestock production, simultaneously with taking care of so-called "point-source pollution" caused by excessive livestock concentration, as well as promotion of other measures and activities which are conditioned by the 
requirements for harmonizing domestic regulations and practice with the EU standards;

- forestation:

○ use of areas for ore exploitation and processing;

$\circ$ areas in alluvial plains along rivers, where high-level ground waters are suitable for cultivating hydrophilic species;

$\circ$ quicksand areas (forestation aimed at binding and prevention of unfavourable erosion effects);

$\circ$ and soils endangered by erosion (Spatial Plan for the Kostolac's Coal Basin Special Purpose Area, 2013).

SEIA is an instrument that helps integration of goals and principles of sustainable development when making decisions about spatial planning, taking into consideration the necessity of avoiding or restricting negative effects on the environment, human health and social-economic status of the population.

\section{FINAL CONSIDERATIONS}

Legal and planning regulations recognize the importance of protecting and preserving land resources and stipulate measures and conditions for utilization with the aim of preventing degradation phenomena and/or reduction of land resources.

Legal regulations comprehensively stipulate measures and methods of utilization, protection and preservation of land resources, at the same time including the possibility of non-rational and inadequate management and/or utilization of land and forests. Illegal and uncontrolled conversion of agricultural and forest land into construction and mining land is not a rare phenomenon, which indicates that the institutions of the Republic of Serbia have difficulty in controlling the implementation of legislative acts. Private and partial interests still have an important place in space utilization. The owner of forest or agricultural land is prevented from keeping and using such land if the executive power, in line with the law, stipulates the repurposing of such land for the purposes which are not in line with generally socially useful or state-useful goods.

Insufficient harmonization and lack of integrity of the legal regulations result in the unsynchronized and difficult implementation of laws, bylaws and planning acts. The content of planning documents, depending on the type of plans, stipulates guidelines for sustainable management and utilization of land, forests and other factors of the environment; however, 
Review paper: doi:10.5937/ZemBilj1902051B

inadequate implementation of planning regulations creates negative effects on land as the environmental element, the environment on the whole, as well as the entire society. Another problem is the lack and absence of necessary information, opinions and proposals prepared for the public participation in the procedures of plan production, accounting for a potentially missing contribution by better-quality decisions in the plan production procedures.

In addition to the improvement of legal framework, the work on the wider concepts such as "a learning region" would contribute to the land quality improvement, all with the view to raising the awareness of the primary and secondary users of land of the proper attitude towards this irreplaceable resource (Stojkov, Pantić, 2006; Pantić, 2007).

\section{Acknowledgements}

The paper was prepared within the scientific projects No. TR 36036 and No. III 47014, financed by the Republic of Serbia Ministry of Education, Science and Technological Development in the period 2011-2019.

\section{REFERENCE:}

Bezbradica Lj., (2013), Problems of torrential floods and erosion processes from the aspect of European directives, domestic legal and planning regulations, Master Thesis, Belgrade:Faculty of Forestry.

Institute of Architecture and Urban and Spatial Planning of Serbia (2012), Special Purpose Area Spatial Plan for Kostolac Coal Basin (2013), Belgrade.

Institute of Architecture and Urban and Spatial Planning of Serbia (2017), Special Purpose Area Spatial Plan for the accumulation basin "Prvonek", Belgrade.

Josimović B., Milijić S., Bezbradica Lj., (2019) Forest windbreaks serving a function of the agricultural land shield from the negative effects of wind, 4th World Congress on Agroforestry, Montpellier, France, 20th-22nd May 2019, p. 359.

Law on Agricultural Land (2006), Official Gazette of the Republic of Serbia, Nos. 62/06, 65/08 - other law, 41/09, 112/15, 80/17 and 95/18 - other law.

Law on Environmental Protection (2009), Official Gazette of the Republic of Serbia, Nos 36/2009, 88/2010, 91/2010 - corrected, 14/2016 and 95/2018 - other law.

Law on Forests (2010), Official Gazette of the Republic of Serbia, Nos. 30/10, 93/12, 89/15 and 95/18 - other law.

Law on Land Protection (2015), Official Gazette of the Republic of Serbia, No. 112/15. 
Review paper: doi:10.5937/ZemBilj1902051B

Law on Spatial Planning and Construction (2009), Official Gazette of the Republic of Serbia, Nos. 72/09, 81/09 - decision of the Constitutional Court, Nos. 64/10, 24/11, 121/12, 42/13 - decision of the Constitutional Court, No. 50/13 - decision of the Constitutional Court, No. 98/13 - decision of the Constitutional Court, Nos. 132/14, 145/14, 83/18 and $31 / 19$.

Pantić M. (2006), Soil Treatment in Legislative, in Responsible Use of Soil and Land and Regional Development, (ed.) Kvarda W., IP SOIL II project, Academia Danubiana, Issue 3, pp. 42-46.

Pantić M. (2007), Subotica Municipality as a Learning Region in Responsible Use of Soil and Land and Regional Development, In SPATIUM International Review No. 15-16, pp. $77-79$.

Republic of Serbia, the Ministry of Agriculture, Forestry and Water Management of the Republic of Serbia, the Forest Directorate (2009), the National Forest Inventory of the Republic of Serbia, Belgrade.

Stojkov B., Pantić M. (2006),Spatial Planning and Issues on Sustainable Soil Use, in the Book of Congress Proceedings at scientific congress First Congress of Serbian Geographers, Soko Banja, Serbia, pp. 151-160.

Stojkov B., Pantić M., (2007), The Soil Use in Mountain Areas and Demographic Changes, in Responsible Use of Soil and Land and Regional Development, (ed.) Kvarda W., IP SOIL II project, Academia Danubiana, Issue 4, pp. 24-26. 


\title{
Korišćenje i zaštita zemljišta: Planiranje i zakonski propisi u Srbiji
}

\author{
Ljubiša Bezbradica*a, Marijana Pantića $^{*}$, Aleksandra Gajića

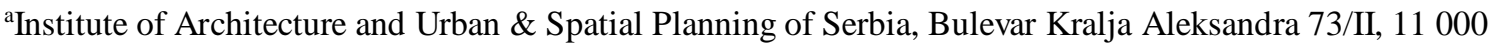 \\ Belgrade, Serbia \\ *Corresponding author: ljubisa@iaus.ac.rs
}

IZVOD: Zemljište, kao jedan od osnovnih faktora životne sredine, je pod velikim uticajem intenzivne poljoprivredne proizvodnje, urbanizacije, rudarstva i erozije prouzrokovane antropogenim faktorom, sto lako može rezultirati njegovom degradacijom. Neplanirana upotreba zemljišta povećava rizik od degradacije i smanjenje zemljišnog resursa. Hemijsko zagađenje, nepovoljne fizičke i mehaničke karakteristike, poremećaj i proces akumulacije, okupiranje zemljišta infrastukturom predstavlja samo nekoliko oblika degradacije zemljišta. Najveći deo zemljišta u Republici Srbiji je pokriveno šumom, a tek potom poljoprivrednim zemljištem, vodom i građevinskim zemljištem. Korišćenje, upravljanje i zaštita zemljišta su regulisani zakonodavnim i planskim dokumentima, koji su i predmet ovog rada. $U$ prvom delu analize dokumenata, akcenat je stavljen na preispitivanju relevatnih zakona usvojenih u Republici Srbiji, kao što su Zakon o šumama, Zakon o prostornom planiranju i izgradnji, Zakon o zaštiti životne sredine, Zakon o zaštiti zemljišta, Zakon o poljoprivrenom zemljištu, imajući u vidu činjenicu da zakonodavstvo čini osnovu za dalju primenu menadžmenta planiranja i nadgledanja korišćenja svih tipova zemljišta. Drugi deo ovog preglednog rada se odnosi na planske akte kao pionirske dokumente u integralnom pregledu prostora, i/ili svih aktivnosti u njemu. Za tu svrhu je izabrano nekoliko prostornih planova za različite oblasti i različite primarne funkcije korišćenja zemljišta. U zaključku ovog rada se objašnjava simbioza zakonodavstva i planskih dokumentata i/ili njihova primena, kao i značaj takve simbioze na funkciju zemljišta i njegovo održivo korišćenje u Republici Srbiji.

Ključne reči: korišćenje zemljišta, zaštita zemljišta, zakonodavstvo, prostorno planiranje, Srbija.

Primljeno 24.07.2019 